HANNA BIAS - KATOWICE

\title{
„KOŚCIELNE ZBIORY MUZYCZNE W BIBLIOTEKACH POLSKICH”. GNIEZNO, 26-28 WRZEŚNIA 2012 ROKU.
}

Pod Honorowym Patronatem Arcybiskupa Metropolity Gnieźnieńskiego, Prymasa Polski, Józefa Kowalczyka oraz Starosty Gnieźnieńskiego Dariusza Pilaka w dniach 26-28 września 2012 roku miała miejsce konferencja „Kościelne zbiory muzyczne w bibliotekach polskich". Spotkanie zostało zorganizowane przy współpracy Sekcji Bibliotek Muzycznych SBP, Archidiecezjalnej Komisji ds. Śpiewu, Muzyki Kościelnej i Służby Liturgicznej, Muzeum Archidiecezjalnym, Archiwum Archidiecezjalnym oraz Studium Muzyki Kościelnej w Gnieźnie. Instytucją wspomagająca konferencję objęła Federacja Bibliotek Kościelnych FIDES. Patronatu medialnego udzieliło Radio plus Gniezno.

Konferencja odbyła się w Muzeum Archidiecezjalnym, gromadząc reprezentantów z największych polskich ośrodków naukowych - Uniwersytetu Muzycznego Fryderyka Chopina w Warszawie, Uniwersytetu im. Adama Mickiewicza w Poznaniu, Uniwersytetu Jagiellońskiego w Krakowie, Uniwersytetu Kardynała Stefana Wyszyńskiego w Warszawie, Uniwersytetu Szczecińskiego (Biblioteka Wydziału Teologicznego), Uniwersytetu Śląskiego (Biblioteka Teologiczna) w Katowicach, Uniwersytetu Warszawskiego, Uniwersytetu we Wrocławiu, Akademii Muzycznej im. K. Szymanowskiego w Katowicach, Akademii Muzycznej im. S. Moniuszki w Gdańsku, Biblioteki Śląskiej w Katowicach, Narodowego Instytutu Fryderyka Chopina w Warszawie, Śląskiego Towarzystwa Muzyki Kościelnej we Wrocławiu, Biblioteki Narodowej (Centrum RISM) w Warszawie, Centralnej Redakcji RISM we Frankfurcie nad Menem oraz Archiwum Archidiecezjalnego w Gnieźnie.

Zaproszenie na konferencję przyjęli również przedstawiciele bibliotek należących do Federacji Bibliotek Kościelnych FIDES, zrzeszających biblioteki teologiczne, seminaryjne, diecezjalne i zakonne. W spotkaniu uczestniczyli bibliotekarze, archiwiści, badacze-muzykolodzy, organiści, studenci muzykologii oraz osoby związane z muzyką kościelną z całej Polski.

W inaugurującym wystąpieniu Prymas Polski, abp Józef Kowalczyk zaakcentował symboliczny charakter miasta Gniezno jako miejsca obrad mówiąc: „Przychodzicie do źródła życia narodowego i kościelnego w Polsce”. Było to nawiąza- 
nie do wygłoszonej katechezy przez bł. Jana Pawła II w 1979 roku, wspomniał również słowa Benedykta XVI aby dążyć do przywrócenia dziełom liturgicznym ich życia poprzez przywracanie ich do użytku. Metropolita gnieźnieński uznał tematykę konferencji, związaną ze zbiorami muzyki kościelnej rozprzestrzenionej w różnych bibliotekach i archiwach jako okazję do lepszego poznania tych materiałów, które są świadectwem wiary poprzednich pokoleń oraz szansą na przypomnienie i zwrócenie uwagi na dziedzictwa kościelnej muzyki sakralnej. Dzieła te „zostały stworzone po to, aby wielbić Boga, aby oddać Mu należną chwałę, aby człowiek mógł wyśpiewać swoją pieśń dla Pana" - skomentował Prymas. Potrzebę organizowania takich spotkań podkreślił Starosta Gnieźnieński Dariusz Pilak, który zaznaczył istotny wymiar konferencji jako poznanie wkładu muzyki kościelnej na historię polskiej kultury. Joanna Pasztaniec-Jarzyńska, członek Prezydium Zarządu Głównego Stowarzyszenia Bibliotekarzy Polskich przywitała oraz skierowała kilka słów do prelegentów oraz słuchaczy konferencji.

Przebiegiem obrad kierował Stanisław Hrabia, przewodniczący Sekcji Bibliotek Muzycznych SBP - Polskiej Grupy Narodowej IAML, który otwierając konferencję podkreślił wagę tematu jakim są kościelne zbiory muzyczne i potrzebę scalenia środowiska pod wieloma aspektami, m.in. wymianę doświadczeń oraz wiedzy, współpracę na polu badawczym, wykonawczym i dokumentacyjnym. Warto też zaznaczyć, że Sekcja Bibliotek Muzycznych SBP - Polska Grupa Narodowa IAML powstała w 1964 r., skupiając w swym gronie bibliotekarzy pracujących w akademiach i uniwersytetach muzycznych, instytutach muzykologii, towarzystwach muzycznych oraz oddziałach muzycznych bibliotek publicznych i uniwersyteckich. Jednym z podstawowych założeń działalności Sekcji jest integrowanie środowiska bibliotekarzy muzycznych poprzez organizowanie konferencji tematycznych i spotkań roboczych.

Główną przyczyną zorganizowania konferencji było doskonalenie i pogłębianie wiedzy, a także wymiana opinii, myśli, poglądów oraz doświadczeń naukowych w zakresie muzyki kościelnej. Zagadnienia obejmowały konserwację oraz ochronę zbiorów, popularyzację, historię, aspekty badawcze i dokumentacyjne oraz stan kościelnych zbiorów muzycznych w bibliotekach i archiwach. W spotkaniu uczestniczyło około 45 osób w tym 32 prelegentów. Obrady konferencji rozłożono na trzy dni, w ciągu których przeprowadzono sześć następujących po sobie sesji tematycznych przeplatanych dyskusjami.

Sesję pierwszą poprowadził Stanisław Hrabia (UJ, Kraków) zapraszając pierwszego prelegenta Mariusza Wronę (NIFC, Warszawa) o wygłoszenie referatu Miejsce muzyki kościelnej we wspótczesnej liturgii traktującym o kondycji polskiej muzyki religijnej we współczesnej praktyce. W słowie początkowym nawiązano do dwóch głów kościoła Piusa X oraz Jana Pawła II, którzy uważali muzykę za integralną część liturgii, a wykonywane utwory jako siłę sprawczą pobudzającą do jeszcze większej pobożności. Według prelegenta kondycja polskiej muzyki religijnej jest zła, a rozważania ukazały, że jest to swego rodzaju praktyka spłaszczona, która wiernych pozbawia sięgnięcia „nieosiągalnego”. Jako druga wystąpiła Hanna Nizińska (UAM, Poznań) z tekstem Działalność edytorska ks. Józefa Surzyńskiego w świetle idei cecyliańskich prezentując główne 
idee ruchu odnowy katolickiej muzyki kościelnej zwanego cecylianizmem zainicjowanego w Niemczech w II poł. XIX wieku. Cecylianizm charakteryzował się dbaniem o muzykę zgodnie z przepisami liturgicznymi. Wykład poświęcony był również dokonaniami edytorskimi prekursora tych idei w Polsce ks. Józefa Surzyńskiego. Kolejne dwa referaty skupiały się wokół problemów identyfikacji dzieł religijnych znajdujących się w klasztornych kolekcjach i archiwach oraz zgodności opisów bibliograficznych w międzynarodowym katalogu źródeł muzycznych RISM z rzeczywistymi manuskryptami. Zaprezentowali się: Guido Klaus (RISM-Zentralredaktion, Frankfurt nad Menem) z tekstem RISM: $c a$ taloguing music sources - increasing concordances - identifying musical Works oraz Maciej Jochemczyk (UJ, Kraków) wygłaszający referat: Problemy atrybucji dziet religijnych zachowanych w przekazach rękopiśmiennych. Casus twórczości mszalnej Franciszka Perneckhera. W II panelu konferencji prowadzonym przez ks. Andrzeja Januchowskiego (Modliszewko) wystąpiła Hanna Bias (AM, Katowice) przedstawiając Kościelne zbiory muzyczne w Bibliotece Gtównej Akademii Muzycznej im. Karola Szymanowskiego w Katowicach. Rekonesans badawczy. Zbiory Biblioteki prelegentka podzieliła na kilka działów, m.in. księgi liturgiczne (zaprezentowano mszał z 1690 roku); kancjonały, śpiewniki i książeczki do nabożeństwa; sakralną muzykę chóralną; muzykę liturgiczną wokalno-intrumentalną; chorały czyli akompaniamenty do pieśni kościelnych gdzie zaprezentowano sylwetki trzech ślązaków Karola Hoppe, Thomasa Cieplika, Józefa Nachbara oraz zbiory użytkowej muzyki organowej. Materiały te szacowane są na około 23 tyś. egzemplarzy co stanowi $1 / 3$ całych druków muzycznych. Sesja II przede wszystkim skupiała się na bogactwie druków religijnych, zbiorów liturgicznych, dokumentów dźwiękowych znajdujących się w bibliotekach naukowych, parafialnych, archiwach. Anna Michalska (AM, Gdańsk) oraz Dorota Stefaniak (AM, Gdańsk) w referacie Msze chóralne oraz pieśni maryjne ze zbiorów Biblioteki Głównej Akademii Muzycznej w Gdańsku - przyczynek do badań nad repertuarem muzyki kościelnej XIX/XX w. przedstawiły wybrane druki, usystematyzowane $\mathrm{w}$ dwóch kategoriach: msze chóralne oraz pieśni maryjne kompozytorów polskich będących w większości muzykami kościelnymi (Zygmunt Moczyński, Mieczysław Żukowski, Franciszek Olszewski). Utwory te pisane były z myślą o konkretnych artystach do wykonania podczas liturgii. Głównym celem wystąpienia było zwrócenie uwagi na kompozycje nieznane, pisane z myślą o liturgii i zachęcenie do wzbogacenia repertuaru muzyki kościelnej XXI wieku. Uczestnicy spotkania mieli również możliwość przesłuchania prezentowanych utworów, które można obecnie znaleźć online w Pomorskiej Bibliotece Cyfrowej. Trzeci referat, Pobożny pielgrzym. Pieśni patnicze $w$ drukach religijnych $z$ wydawnictw Franciszka Gielnika, Teofila Nowackiego i Karola Miarki wygłosiła Małgorzata Witowska (BŚ, Katowice) przedstawiając ruch pielgrzymkowy na terenie Śląska oraz związane z tym czynności śpiewoka czyli organizatora wycieczek do ośrodków pątniczych. Intensyfikacja ruchu pielgrzymkowego nastąpiła na przełomie XIX i XX wieku oraz w latach międzywojennych ze względu na połączenia wartości religijnych z czynnikami narodowymi. Do zakresu obowiązków śpiewoka należało przygotowanie oraz prowadzenie pątników do sanktuariów, a z pomocą 
przychodziły kalwaryjki, modlitewniki czy zbiory własnych pieśni. Pieśni pielgrzymkowe umacniały wiarę, przekazywały tradycyjną pobożność, a także pomagały pokonywać trudności drogi ułatwiając marsz. Prelegentka przedstawiła pieśni pątnicze wydawnictw Franciszka Gielnika, Teofila Nowackiego i Karola Miarki znajdujące się w Bibliotece Śląskiej w Katowicach. Po krótkiej przerwie głos zabrał ks. Michał Sołomieniuk (Archiwum Archidiecezjalne, Gniezno) opisując Muzykalia w zbiorach Archiwum Archidiecezjalnego w Gnieźnie oraz ich odkrywca-ks. Władysław Zientarski oraz Marcin Konik (UJ, Kraków) wypowiedział się na temat Johann Valentin Rathgeber - recepcja twórczości w świetle polskich źródet. Po wysłuchaniu wszystkich referatów zaproszono uczestników na mszę św. w Katedrze Gnieźnieńskiej pod przewodnictwem ks. kanonika Ryszarda Figla, a następnie wysłuchano koncertu organowego w wykonaniu organisty Bazyliki Archidiecezjalnej Ryszarda Superczyńskiego.

Sesję III rozpoczynającą drugi dzień konferencji prowadziła Aleksandra Patalas (UJ, Kraków), w której referaty wygłosili: ks. Andrzej Januchowski (Modliszewsko) Prywatna biblioteka Floriana Bogackiego, organisty gnieźnieńskiego; Marek Bebak (Kraków) Muzycy w księdze wpisów do Bractwa Szkaplerza Świętego z Archiwum OO. Karmelitów na Piasku w Krakowie; Jolanta ByczkowskaSztaba (BN, Warszawa) Rękopisy i druki muzyczne w zbiorach archiwum Opactwa OO. Cystersów w Mogile oraz Magdalena Walter-Mazur (UAM, Poznań) Próba wyodrębnienia i charakterystyka muzycznej spuścizny benedyktynek ze zbiorów Biblioteki Diecezjalnej w Sandomierzu. Po krótkiej przerwie kawowej rozpoczęła się IV sesja poprowadzona przez Remigiusza Pośpiecha (UWr). Pierwsza prelegentka Ewa Hauptman-Fischer (BUW) wygłosiła referat Muzykalia cysterek trzebnickich $w$ zbiorach Biblioteki Uniwersyteckiej $w$ Warszawie przybliżając niewielki zbiór muzykaliów (40 rękopisów) pochodzących z klasztoru cysterek w Trzebnicy należący w XVIII wieku do rektora trzebnickiego chóru Gedeona Riedla. Badania identyfikacji utworów nie potwierdziły poprzedniej hipotezy, jakoby autorstwo należało do kapelmistrzów. Można uznawać, że są to kopiowane utwory lokalnie działających kompozytorów śląskich. Wiele materiałów zachowanych jest anonimowo. Zbiór ten został ukazany również pod względem funkcji wykorzystywania i można wnioskować, że muzyka towarzyszyła cysterkom w wielu momentach życia klasztornego, towarzyszyła liturgii mszy świętej niedzielnej i świątecznej, modlitwie brewiarzowej, zwłaszcza nieszporom, a dodatkowe modlitwy i nabożeństwa odprawiano z udziałem muzyki, która służyła wytchnieniu i odpoczynku zakonnic. Kolejny wysłuchany temat to Twórczość Johanna Georga Clementa (1710-1794) kapelmistrza katedry wrockawskiej przechowywana w zbiorach Biblioteki Uniwersyteckiej w Warszawie i Biblioteki Kapitulnej we Wrocławiu zaprezentowany przez Ludmiłę Sawicką (BUW), natomiast wykład Elżbiety Jasińskiej-Jędrosz przedstawiał życie i twórczość współczesnego kompozytora, organisty i pedagoga Mariana Sawy (1937-2005), skupiając się na tej dziedzinie jego twórczości, jaką są dzieła o charakterze religijnym. Autorka omawiała poszczególne grupy utworów religijnych, takich jak utwory organowe, utwory na chór i organy, na głos solowy i organy, na chóry żeński, męski i mieszany a cappella pieśni i piosenki solowe oraz kolędy na różne zespoły. Referat Rę- 
kopisymuzykireligijnejMarianaSawywzbiorach BibliotekiUniwersyteckiejwWarszawie zawierał również wykaz tych utworów religijnych Mariana Sawy, które w formie rękopisów trafiły jako dar do Archiwum Kompozytorów Polskich Biblioteki Uniwersyteckiej w Warszawie. Ostatnią prelegentką była Katarzyna Janczewska-Sołomko (BN, Warszawa) prezentująca Polskie i polonijne nagrania utworów religijnych $w X X$-leciu międzywojennym. Po wysłuchaniu wszystkich tematów drugiego dnia konferencji uczestnicy mieli okazję zwiedzić Katedrę Gnieźnieńską, jej podziemia oraz słynne drzwi gnieźnieńskie ukazujące żywot św. Wojciecha. Zostały również udostępnione najcenniejsze okazy przechowywane w Muzeum Archidiecezjalnym w Gnieźnie, które w przerwach między obradami można było zobaczyć.

Ostatni dzień konferencji rozpoczął się od sesji V poprowadzonej przez Magdalenę Walter-Mazur (UAM, Poznań), która jako pierwszą do wygłoszenia referatu poprosiła Ewę Bielińską-Galas, przedstawiającą Piętnastowieczny graduat $z$ kościoła św. Idziego w Gtubczycach ms. BOZ Cim 151 w kontekście bernardyńskiej tradycji muzycznej, następnie prof. Uniwersytetu Kardynała Wyszyńskiego w Warszawie Czesław Grajewski zaprezentował Kartuskie źródła oficjum brewiarzowego w polskich zasobach archiwalnych i bibliotecznych, kolejno Hubert Wojno (UMFC, Warszawa) z tematem Stare druki liturgiczno-muzyczne przechowywane w zbiorach parafii pw. św. Anny w Dąbrówce Kościelnej oraz Aleksandra Patalas (UJ, Kraków) przedstawiła Uwagi do repertuaru kapel w Pilicy i Gidlach. W ostatnim panelu VI prowadzony przez Iwonę Bias (AM, Katowice) wysłuchano Alinę Mądry (UAM, Poznań) z referatem Zbiór muzykaliów po poznańskiej kapeli farnej-miejskiej a zachowane muzyczne inwentarze z Katedry-konfrontacja repertuaru (ze zbiorów Archiwum Archidiecezjalnego w Poznaniu); Tomasza Kmitę z tematem Zbiory muzyczne kantoratu kościoła św. Krzysztofa we Wrocławiu gdzie odwołał się do części księgozbioru, która stanowi pozostałości dawnej biblioteki kantoratu kościoła św. Marii Magdaleny we Wrocławiu. Ze względu na swe szczególne znaczenie dla śląskich ewangelików, posiadał on bardzo bogate życie muzyczne, a co za tym idzie bogate zbiory. Niewyjaśniona jest historia translokacji nut ze św. MM do kościoła św. Krzysztofa, jednak wiadomo, że ogółem sama część muzykaliów będących swoistym spadkiem obejmuje około 250 kompozycji ponad 100 autorów. Ostatnią osobą poproszoną o wygłoszenie tematu był profesor Uniwersytetu Wrocławskiego Remigiusz Pośpiech omawiający XIXwieczne zbiory muzyczne Kościoła pw. Podwyższenia Krzyża św. w Opolu. Zaproszenie do udziału w konferencji zostało skierowane również na ręce Przewodniczącego Federacji Bibliotek Kościelnych Fides ks. dr Jerzego Witczaka dyrektora Biblioteki Papieskiego Wydziału Teologicznego. Zważywszy na to, że tematem konferencji były „Kościelne zbiory muzyczne w bibliotekach polskich” nie mogło zabraknąć przedstawicieli bibliotek kościelnych. W imieniu bibliotekarzy Federacji FIDES głos zabrała Bogumiła Warząchowska z-ca przewodniczącego - kierownik Biblioteki Teologicznej Uniwersytetu Śląskiego w Katowicach. Podziękowała organizatorom Sekcji Bibliotekarzy Muzycznych SBP za podjęcie ciekawego tematu i za zaproszeniu do udziału w obradach. W swoim wystąpieniu z uznaniem i podziwem odniosła się do wystąpień prelegentów i ich konkretnych działań 
w obszarze ochrony zbiorów muzycznych. Podkreśliła konieczność współpracy w zakresie udostępniania i opracowania zbiorów muzycznych gromadzonych i przechowywanych w bibliotekach kościelnych. Obradom towarzyszyły liczne dyskusje gdzie podkreślano potrzebę kolejnych spotkań w celu wymiany doświadczeń, informacji; kontynuację rozbudzania świadomości ochrony muzycznych zabytków; konieczność dalszych badań oraz katalogowania i opracowywania tak cennych i ważnych materiałów.

Konferencja „Kościelne zbiory muzyczne w bibliotekach polskich” w Gnieźnie niewątpliwie przyczyni się do większego zrozumienia roli i korzyści płynących z zacieśnienia współpracy bibliotekarzy z różnych bibliotek w kraju. Podsumowanie obrad przypieczętował Stanisław Hrabia, który podkreślił znaczenie organizowania i uczestniczenia w takich spotkaniach. 